\title{
The Modeling System of Isotherm Adsorption in Mechanism of Myrmecodia Pendans Extracts as the Corrosion Inhibitor in 3, 5\% $\mathrm{NaCl}$ Solution
}

\author{
Atria Pradityana ${ }^{1}$, Sulistijono ${ }^{2}$, Abdullah Shahab ${ }^{3}$ \\ ${ }^{1}$ Department of Mechanical Engineering, Institut Teknologi Sepuluh Nopember, Surabaya 60111, Indonesia \\ ${ }^{2}$ Department of Materials and Metallurgical Engineering, Institut Teknologi Sepuluh Nopember, Surabaya 60111, Indonesia \\ ${ }^{3}$ Department of Mechanical Engineering, Institut Teknologi Sepuluh Nopember, Surabaya 60111, Indonesia
}

\begin{abstract}
In this research, the weight loss experiment is conducted by using the material of API 5L Grade B in 3.5\% NaCl solution. Sarang Semut extract (Myrmecodia pendans) is used as the corrosion inhibitor. The immersion time period of weight loss experiment is 10, 20, and 30 days. The concentration of Sarang Semut extract which is used ranges to 100-500 mg/L. This research aims to determine the appropriate method of isotherms adsorption on each system. This is related to the surface protective layer which is formed on the surface of the Sarang Semut extract adsorption. The result of this experiment shows that with the time period of 10 days immersion, it follows the equation of the mixture adsorption type. Meanwhile, with the time period of 20 and 30 days, it follows the equation of Freundlich with the physical adsorption type.
\end{abstract}

Keywords: sarang semut, inhibitor, $\mathrm{NaCl}$, adsorption mechanism, modeling adsorption

\section{Introduction}

In the industrial application, the often used inhibitor is the chemical synthesis inhibitor in which it is an inhibitor with a compound containing the silicate, borate, chromate, dichromate, tungstate, molybdate, phosphate and arsenate. However, these compounds are not eco-environment, toxic, and expensive. Therefore, it is developed an alternative corrosion inhibitor which is eco-environment or well-known as the green inhibitor [1]. The green inhibitor contains the atoms of $\mathrm{N}, \mathrm{O}, \mathrm{P}, \mathrm{S}$, and other atoms which have the free electron pairs. The elements which contain the free electron pairs will form the complex compounds with the metal [1].

Nowadays, there are many researches on green inhibitor such as done by Von Fraunhofer et al (2001) [2] by using the tobacco extracts on the steel which was coated by the copper in $3.5 \% \mathrm{NaCl}$ media. The tobacco extract with the concentration of $100 \mathrm{ppm}$ could inhibit corrosion by $90 \%$. The effectiveness of the inhibitor green was caused by the extract containing the nitrogen which forms the complex compounds. Another research is conducted by El-Etre et al (2005) [3] showing that the extract of Lawsonia could be used as the inhibitor of carbon steel in $3.5 \% \mathrm{NaCl}$ media. The extract gave the efficiency of $91.01 \%$ at the concentration of $800 \mathrm{ppm}$.

The extract of Sarang Semut (Myrmecodia pendans) has been developed as the green inhibitor because it contains the antioxidant. In the field of medicine, the extracts of Sarang Semut has been proved to inhibit the growth of HeLa cells and MCM-B2 which are the type of cancer cells (Soeksmanto, 2010) [4]. The result of HPLC experiment proves that Sarang Semut contains flavonoid [5].

In the previous researches, the extract of Sarang Semut had been used to protect the material of API 5L Grade B in 3.5\%
$\mathrm{NaCl}$ with the inhibitor concentration of $0,500,1000,1500$, 2000 and $2500 \mathrm{ppm}$. The highest inhibitor efficiency was shown at a concentration of $500 \mathrm{ppm}$ which was $90.62 \%$ by using the experiment of potentiodynamic polarization. This was because Sarang Semut contains functional groups of alcohol group, alkaloid group, as well as the element of $\mathrm{N}$ and $\mathrm{O}$ which had been tested by using the Gas Chromatography [6]. In 2014, Atria [7] conducted a research to narrow the range of concentration variation ranging from $0,100,200,300,400$ and $500 \mathrm{ppm}$. The corrosion media and the inhibitor extract used were the same which were $3.5 \%$ $\mathrm{NaCl}$ and the extract of Sarang Semut. Yet, this research does not describe the type of adsorption which occurs so that the mechanism of inhibition occurring between Sarang Semut extract and the material surface is not clear.

Based on the consideration above, a deeper research will be conducted by the writer to find out the type of adsorption occurs in the research of Atria 2014 [7]. In this research, it will be analyzed the mechanism of adsorption by using the equations of Langmuir, Freundlich, and Temkin. By knowing the adsorption equation which is followed, it can be calculated the value of the free energy as $\left(\Delta G_{a d s}^{o}\right)$. The value of $\left(\Delta G_{a d s}^{o}\right)$ will be used to determine the type of adsorption occurring whether it is the adsorption of physics, chemistry, or the mixture of both.

\section{Experimental}

\subsection{The specimen preparation}

Specimen used is API 5L steel grade B. For the weight loss experiment, the specimen is formed as a coupon with dimension of $20 \times 20 \times 3 \mathrm{~mm}$. Before the immersion, the specimen surface is smoothed by using the rubbing the paper so that the specimen surface is free from corrosion product which is flat and smooth [7].

\section{Volume 5 Issue 6, June 2016 www.ijsr.net}




\section{International Journal of Science and Research (IJSR) \\ ISSN (Online): 2319-7064}

Index Copernicus Value (2013): 6.14 | Impact Factor (2015): 6.391

\subsection{The solution preparation}

The solution of $3.5 \% \mathrm{NaCl}$ is made by dissolving 35.24 grams of sodium chloride in $1000 \mathrm{ml}$ measuring glass until the limit mark. Then it is added with the extract of Sarang Semut (Myrmecodia pendans) at the concentration of 100 , 200, 300, 400, and $500 \mathrm{mg} / \mathrm{L}$ [7].

\subsection{The weight loss experiment}

The specimen is weighed to obtain the initial weight then it is immersed in $3.5 \% \mathrm{NaCl}$ solution which is added with the inhibitor from the range of 0 to $500 \mathrm{mg} / \mathrm{L}$. The time period of immersion is 10, 20, and 30 days. The solution of $\mathrm{HCl} 500$ $\mathrm{ml}$ and hexamthylene tertamine 3.5 grams are added with $1000 \mathrm{ml}$ of aquades to clean the specimen [7]. To calculate the inhibition efficiency, it is used the following equation:

$$
\begin{gathered}
C R=\frac{\text { K.W }}{\text { D.A.T }} \\
\% E I=\frac{C R_{0}-C R_{1}}{C R_{0}} \times 100 \%
\end{gathered}
$$

In which $\mathrm{K}$ is the constant corrosion rate, $\mathrm{W}$ is the weight of the specimen, $\mathrm{D}$ is the density, and $\mathrm{A}$ is the wide of the specimen surface. In addition, CR0 is the efficiency without the addition of inhibitor and CR1 is the efficiency with the addition of inhibitor.

\subsection{The model of isotherm adsorption}

The adsorption process is conducted by involving 5 concentration variations of inhibitor extracts consisting of $100,200,300,400$ and $500 \mathrm{ppm}$. The adsorption process is carried out by applying the immersion method. The time period of immersion is 10,20 , and 30 days. The purpose of involving 5 concentration variations of inhibitor extracts is getting the parameters of Isothermal Adsorption. The Isothermal adsorptions tested in this experiment are namely Langmuir, Freundlich, and Temkin. In this experiment, the type of adsorption isotherm is obtained which best fits with the obtained data. The followings are linearization equations presented in the equations of (3) Langmuir, (4) Freundlich, and (5) Temkin. Whereas, the equation (6) is used to calculate the value of free energy.

The equation of Langmuir linearization: [8]

$$
\frac{C}{\theta}=\frac{1}{k_{\text {ads }}}+C
$$

The equation of Freundlich linearization: [8]

$$
\theta=k_{a d s} C
$$

The equation of Temkin linearization: [8]

$$
\theta=\frac{R T}{b_{T}} \ln A_{T}+\frac{R T}{b_{T}} \ln C
$$

For calculating the value of $\Delta G_{a d s}^{o}$ free energy, it is used this following equation: [8]

$$
k_{a d s}=\frac{1}{55,5} \exp \left(\frac{-\Delta G_{a d s}^{o}}{R T}\right)
$$

Where :

$$
\begin{array}{ll}
\mathrm{C} & =\text { Concentration of inhibitor }(\mathrm{mg} / \mathrm{L}) \\
\mathrm{k}_{\mathrm{ads}} & =\text { Constant of adsorption } \\
\mathrm{T} & =\text { Temperature }(\mathrm{K}) \\
\mathrm{R} & =\text { Constant of ideal gas }(8.314 \mathrm{~J} / \mathrm{mol} \mathrm{K}) \\
-\Delta G_{a d s}^{o} & =\text { Free standart energy adsorption }(\mathrm{kJ} / \mathrm{mol})
\end{array}
$$

\section{Results and discussion}

The weight loss experiment is a method used to determine the rate of corrosion and the inhibition efficiency. This method is simple and practical to do but it takes a long time for the immersion process [9]. The mass reduction occurs because the metal is destructed and dissolved into oxidation condition which is caused by the chemical reaction between the metal and its environment. The result of weight loss experiment is shown in Table 1.

The lowest corrosion rate is at the concentration of $500 \mathrm{mg} / \mathrm{L}$

\begin{tabular}{|c|c|c|c|c|c|}
\hline $\begin{array}{c}\text { Time } \\
\text { period of } \\
\text { immersion } \\
\text { (days) }\end{array}$ & $\begin{array}{c}\text { Concentrat } \\
\text { on of } \\
\text { sarang } \\
\text { semut } \\
\text { extract }(\mathrm{C}) \\
(\mathrm{mg} / \mathrm{L}) \\
\end{array}$ & $\begin{array}{l}\text { Corrosion } \\
\text { rate (mpy) }\end{array}$ & $\begin{array}{c}\text { Efficienc } \\
\text { y of } \\
\text { inhibition } \\
(\%)\end{array}$ & $\begin{array}{c}\text { Surface } \\
\text { coverage } \\
(\theta)\end{array}$ & $\theta / \mathrm{C}$ \\
\hline \multirow{6}{*}{10} & 0 & 37,751 & - & - & - \\
\hline & 100 & 18,426 & 51,19 & 0,5119 & 0,005119 \\
\hline & 200 & 17,801 & 52,85 & 0,5285 & 0,002642 \\
\hline & 300 & 17,374 & 53,98 & 0,5398 & 0,001799 \\
\hline & 400 & 17,268 & 54,26 & 0,5426 & 0,001356 \\
\hline & 500 & 11,019 & 70,81 & 0,7081 & 0,001416 \\
\hline \multirow{6}{*}{20} & 0 & 24,979 & - & - & - \\
\hline & 100 & 11,812 & 52,71 & 0,5271 & 0,005271 \\
\hline & 200 & 9,663 & 61,32 & 0,6132 & 0,003066 \\
\hline & 300 & 9,442 & 62,20 & 0,6220 & 0,002073 \\
\hline & 400 & 7,849 & 68,58 & 0,6858 & 0,001714 \\
\hline & 500 & 5,555 & 77,76 & 0,7776 & 0,001555 \\
\hline \multirow{6}{*}{30} & 0 & 16,262 & - & - & - \\
\hline & 100 & 10,526 & 35,27 & 0,3527 & 0,003527 \\
\hline & 200 & 8,9209 & 45,14 & 0,4514 & 0,002257 \\
\hline & 300 & 8,5195 & 47,61 & 0,4761 & 0,001587 \\
\hline & 400 & 5,7102 & 64,89 & 0,6489 & 0,001622 \\
\hline & 500 & 3,9666 & 75,61 & 0,7561 & 0,001512 \\
\hline
\end{tabular}
as much as $5.555 \mathrm{mpy}$ with the time period of immersion 20 days. The optimum efficiency of inhibition that occurs is $77.76 \%$. This is because with the increasing concentration of inhibitor which is added to the corrosive environment, the inhibitor will be adsorbed to the metal surface to form the passive layers that inhibit the reaction between the metal and its environment. In addition, the value of surface coverage will also increase if the concentration of inhibitor increases to. Table 1 shows the parameter summary which is used to draw the plot of each type of adsorption.

Figure 1 shows the equation of Langmuir isotherm adsorption. Figure 2 shows the equation of Freundlich isotherm adsorption and Figure 3 shows similarities of Temkin isotherm adsorption. In each picture, there are 3 graphs showing the difference of the immersion time period. In each immersion time period, it is resulted an equation 


\section{International Journal of Science and Research (IJSR) \\ ISSN (Online): 2319-7064}

Index Copernicus Value (2013): 6.14 | Impact Factor (2015): 6.391

which is used to determine the mechanism of adsorption that occurs.

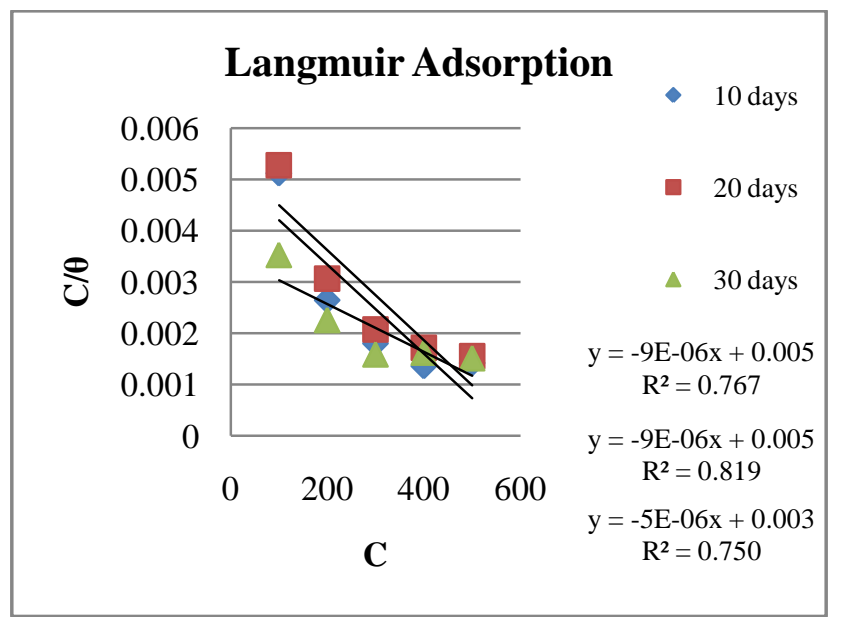

Figure 1. The equation of Langmuir isotherm adsorption

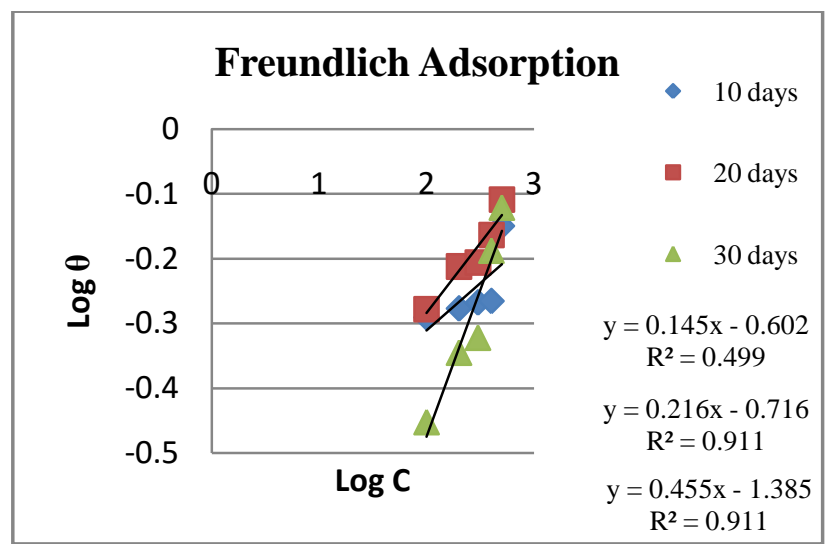

Figure 2. The equation of Freundlich isotherm adsorption

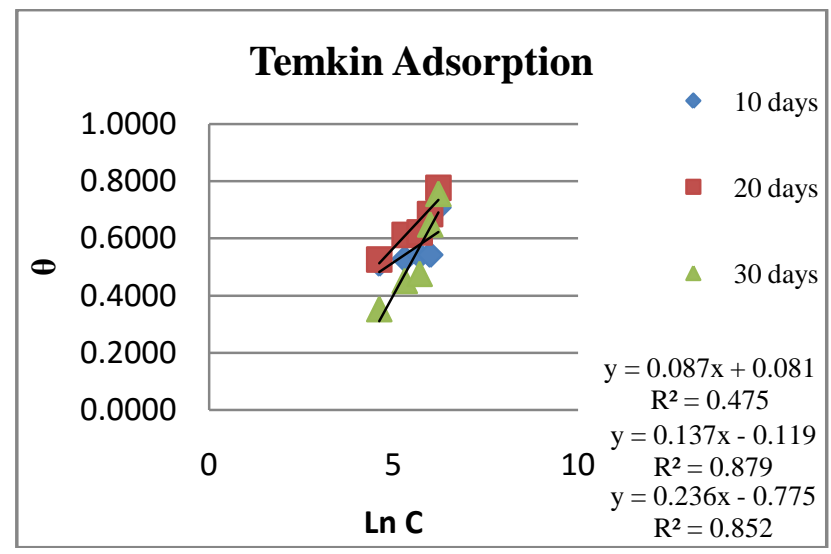

Figure 3. The equation of Temkin isotherm adsorption

From the figure 1, 2, and 3, it is obtained the equations in each adsorption. From the summary, it can be seen that with the immersion time period of 10 days, the equation adsorption follows Langmuir isotherm adsorption. While the immersion time period of 20 and 30 days follows the adsorption equation of Freundlich isotherm adsorption. This selection is based on the value of $\mathrm{R}^{2}$ which is close to 1 . Langmuir isothermal adsorption describes the molecules of Sarang Semut extract that is adsorbed only stick in the outer layer of the material surface or simply form a monolayer. This monolayer formed has the characteristic which is not easily dislodged. Meanwhile, Freundlich isothermal adsorption describes that the protective layer formed is the multilayers. These layers are easily detached. From these equations, it can be determined and calculated the value of $\mathrm{K}_{\mathrm{ads}}$ and $\Delta G_{a d s}^{o}$

Table 2. The summary of the free energy $\left(\Delta G_{a d s}^{o}\right)$ calculation

\begin{tabular}{|c|c|c|c|c|}
\hline $\begin{array}{c}\text { Time period } \\
\text { of } \\
\text { immersion } \\
\text { (days) }\end{array}$ & $\begin{array}{c}\text { Equation of } \\
\text { adsorption }\end{array}$ & $\mathrm{R}^{2}$ & $\mathrm{~K}_{\mathrm{ads}}$ & $\Delta \boldsymbol{G}_{\boldsymbol{a d s}}^{\boldsymbol{o}}$ \\
\hline 10 & Langmuir & $\mathrm{R}^{2}=0,767$ & 200 & $-32,17$ \\
\hline 20 & Freundlich & $\mathrm{R}^{2}=0,911$ & 0,216 & $-9,31$ \\
\hline 30 & Freundlich & $\mathrm{R}^{2}=0,911$ & 0,455 & $-4,78$ \\
\hline
\end{tabular}

Table 2 shows the summary of the calculation results of free energy value. From the results of $\left(\Delta G_{a d s}^{o}\right)$, it can be determined the mechanism of inhibition is formed in the adsorption of physics, chemistry, or a mixture of both. According to some researches which were done previously by El-haddad and Taleb Ibrahim, [10,11] when the value of $\left(\Delta G_{a d s}^{o}\right)>-20 \mathrm{~kJ} / \mathrm{mol}$, the adsorption occurs in physics. If $\left(\Delta G_{a d s}^{o}\right)<-40 \mathrm{~kJ} / \mathrm{mol}$, the adsorption occurs in chemical and if $-40 \mathrm{~kJ} / \mathrm{mol}<\left(\Delta G_{a d s}^{o}\right)<-20 \mathrm{~kJ} / \mathrm{mol}$, the adsorption which occurs is the mixture adsorption. Based on the range of $\left(\Delta G_{a d s}^{o}\right)$, it is understood that with the time period of 10-day immersion, the adsorption which occurs is the mixture adsorption. Based on the range of $\left(\Delta G_{a d s}^{o}\right)$, it is known if the time period of the immersion is 10-day, the adsorption which occurs is the mixture adsorption. If the time period of immersion is 20 and 30 days, the adsorption which occurs is the physical adsorption. Physical adsorption occurs due to the difference of energy or electrical tensile force (van der Wall's). The molecules of Sarang Semut extract are physically bonded to the surface of the material. This type of adsorption is multilayers since each molecule forms a layer on the previous layer and it has reversible characteristic. Whereas, the chemical adsorption occurs because of the chemical bonding that occurs between molecules of Sarang Semut extract and the material surface. Because of the chemical bonding, the surface of the material can form a layer and if this continuous then the surface will not be able to absorb other substances anymore. This adsorption is irreversible.

\section{Conclusion}

The result of this research shows that each the time period of immersion is one system. From the 3 variations of immersion time, it is produced 3 systems with different mechanisms of inhibition. The immersion time period of 10 days follows the Langmuir adsorption equation and adsorption that occurs is the mixture adsorption. The immersion time period of 20 and 30 days follows the Freundlich equation adsorption and adsorption that occurs is the physical adsorption. The physics adsorption has the reversible characteristic while the mixture adsorption has the

\section{Volume 5 Issue 6, June 2016 www.ijsr.net}


combination characteristic between physical and chemical adsorption.

\section{References}

[1] B. R. Pandian. G. S. Mathur, Natural product as corrosion inhibitor for metals in corrosive media areview. Science Direct Materials Letters 62 p.113-116. (2008)

[2] Von Fraunhofer, J.A., G.D. Davis, L.A. Krebs, C.M. Dacres. The Use of Tobacco Extract as Corrosion Inhibitor. Corrosion Paper No. 1558. (2001)

[3] El-Etre, A.Y., Abdallah. M., \& El Tantawy, Z.E. Corrosion Inhibition of Some Metals using Lawsonia Extract. Corrosion Science, 47 p.385-395. (2005)

[4] Soeksmanto, A., M.A. Subroto, H. Wijaya dan P. Simanjuntak. Anticancer Activity for Extracts of Sarang Semut Plant (Myrmecodia Pendans) to Hela and MCM-B2 Cells. Pakistan Journal Biol. Science Vol.13 p.148-151. (2010)

[5] Adam, M.E., Novy, S. Kasim, Yesthilia, A.T., Suryadi, Ismadji, Lien, H.H., Yi-Hsu Ju. 2013. Extraction, Identification and Quantitative HPLC Analysis of Flavanoids from Sarang Semut (Myrmecodia Pendans). Industrial Crops and Products. Vol. 41, pp. 392-396.

[6] Atria, Pradityana., Sulistijono, Abdullah Shahab. Effectiveness of Myrmecodia Pendans Extract as EcoFriendly Corrosion Inhibitor for Material API 5L Grade $\mathrm{B}$ in $3,5 \% \mathrm{NaCl}$ Solution. Advance Material Research Vol. 789 pp.484-491. (2013)

[7] Pradityana. A, Sulistijono, Shahab.A. Application of Myrmecodia Pendans Extract as a Green Corrosion Inhibitor for Mild Steel in 3,5\% NaCl. Trans Tech Publications, Switzerland.. Applied Mechanics and Materials Vol. 493 pp 684-690. (2014)

[8] K.Y.Foo, B.H.Hameed. Insights into the modeling of adsorption isotherm system. Chemical Engineering Journal 156 p.2-10. (2010)

[9] A. Spinelli., F. S. De Souza, "Caffeic acid as a green corrosion inhibitor for mild steel," Corrosion Science 51p.642 - 649 (2009)

[10] El-Haddad, M. N. Chitosan as a green inhibitor for copper corrosion in acidic medium". International Journal of Biological Macromolecules Vol. 55, pp.142149. (2013)

[11] Taleb Ibrahim. The Effect of Thyme Leaves Extraction Corrosiob of Mild Steel in HCl. Progress in Organic Coating 75 (456-462). (2012)

\section{Author Profile}

Atria Pradityana received the Bachelor degrees in Metallurgy and Material Engineering and the Master degrees in Mechanical Engineering from Institut Teknologi Sepuluh Nopember Surabaya (ITS) in 2003 and 2007, repectively. During 2007-2016, she stayed in Corrosion Research Laboratory to study corrosion and inovative material. She now to be lecturer in ITS. 